\title{
Aile İşletmelerinde Kurumsallaşmanın Önemi ve Kurumsallaşma Sürecinde Stratejik Yönetimin Rolü
}

\author{
Münevver BAYAR ${ }^{1 *}$
}

Geliş Tarihi/Received: 23.03.2021

Kabul Tarihi/Accepted: 27.04.2021

Araştırma Makalesi/Research Article

\section{ÖZET}

Küreselleşme ve beraberinde getirdiği rekabetçi ortam aile işletmelerinin sürdürülebilirliğini tehlikeye sokma potansiyeline sahiptir. Kurumsallaşma ve stratejik yönetim ise aile işletmeleri için bu tehlikelerle baş edebilme sürecinde etkin araçlar olabilmektedir. $\mathrm{Bu}$ çalışmanın amacı stratejik yönetimin kurumsallaşma sürecindeki rolü ve etkisinin aile işletmeleri bazında incelenmesidir. Araştırma sonucunda aile işletmelerinde kurumsallaşmanın sağlanmasının stratejik yönetim ilkeleri ile daha mümkün olduğu sonucuna varılmıştır. Ayrıca, rekabette avantaj sağlayabilecek stratejik iş birliklerinin işletmeler için faydalı olduğu; işletmenin stratejik plânının performans farklılıkları prosedürünü de içermesi gerekliliği ve de işletme stratejisinin belirlenmesini takiben ilgili plân ve bütçeler yapılmasının kurumsallaşma politikalarına uygunluğu tespit edilmiştir.

Anahtar Kelimeler: Strateji, Aile İşletmeleri, Stratejik Yönetim, Kurumsallaşma.

\section{The Importance of Institutionalization in Family Businesses and The Role of Strategic Management in Institutionalization Process}

\begin{abstract}
Globalization and the competitive environment it brings with have the potential to endanger the sustainability of family businesses. Institutionalization and strategic management can be effective tools for family businesses to cope with these dangers. The aim of this study is

\footnotetext{
${ }^{1}$ Dr, SGK Ankara Sosyal Güvenlik İl Müdürlüğü Kahramankazan Şehit Ali İhsan Lezgi Sosyal Güvenlik Merkezi, Orcid No: 0000-0002-8077-2160

* Sorumlu yazar/Corresponding author

E-mail/e-ileti: munevverbayar@hotmail.com
} 
to examine the role and effect of strategic management in the institutionalization process on the basis of family businesses. As a result of the research, it was concluded that institutionalization in family businesses is more possible with strategic management principles. In addition, strategic alliances that can provide competitive advantage are beneficial for businesses; it has been determined that the strategic plan of the enterprise includes the procedure for performance differences and the compliance of the relevant plans and budgets with the institutionalization policies following the determination of the business strategy.

Key Words: Strategy, Family Business, Strategic Management, Institutionalization.

\section{GİRIŞ}

Organizasyonlar için en önemli kavramlardan biri sürdürülebilirliktir. Bu kavram ise uzun vadeli planları, hedefleri ve sürdürülebilir başarıyı bünyesinde barındırmaktadır. $\mathrm{Bu}$ bağlamda, örgütlerin uzun dönem hedeflerini gerçekleştirebilmeleri için yerel ve küresel ölçekteki değişimleri dikkatli bir şekilde izlemeleri ve analiz etmeleri gerekmektedir. $\mathrm{Bu}$ süreçte söz konusu aktörlerin iç çevre analizindeki güçlü ile zayıf, dış çevredeki analizde ise karşı karşıya oldukları olanak ve tehdit ögelerini belirlemeleri elzemdir. Nitekim uzun vadeli ve sürdürülebilir başarı için yenilikçi stratejilerin kilit önemi haizdir ve sürdürülebilir başarıyı gerçekleştirmiş güçlü işletmelerin çevresel faktörleri daha iyi analiz ettikleri, imkânları daha dikkatli değerlendirdikleri gözlemlenmektedir (Kebeci, 2011;Aydıner, 2008; Fındıkçı 2011).

Küresel ekonomik ortam, teknolojik ve iktisadi alanlarda hızla değișen ve gelișen yeniliklere sahne olmaktadır. Böylelikle oluşan rekabetçi ortam ise piyasa aktörlerini de aynı şekilde değişisme, gelişime ve de yeniliklere zorlamaktadır. Sonuç itibariyle, bahsedilen piyasa aktörlerinden biri olarak aile işletmeleri de mevcut organizasyonlarında, yönetim yapılarında, sistemlerinde, insan ve bilgi kaynaklarında sürekli yeniliklere ve değişikliklere gitme durumunda kalmaktadırlar (Kebeci, 2011; Aydıner, 2008; Fındıkçı 2011).

Aile işletmeleri kavramı en temel anlamıyla bir ailenin kontrolünde bulunan işletmeler şeklinde tanımlanabilir. Kurumsallaşma uygulamaları ise aile işletmelerinin sürdürülebilirliğine katkı sağlama potansiyeline sahiptir. Bu anlamda, kurumsallaşma kavramı aile işletmeleri açısında daha uzun yıllar süresince ayakta kalmayı sağlama beraberinde devamlılığına engel edebileceği durumların ortadan kalkmasına yardımcı olmak suretiyle aile işletmelerine destek olabilmektedir. Aile işletmelerinin kurumsallaşabilmesi için ise stratejik yönetim etkin bir mekanizma olarak kullanılabilir (Kebeci, 2011; Aydıner, 2008; Fındıkç1 2011). 


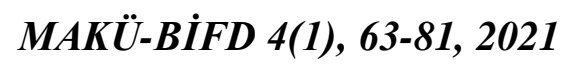

$\mathrm{Bu}$ çalışmanın sorunsalı stratejik yönetimin kurumsallaşma sürecindeki rolü ve etkisinin aile işletmeleri bazında incelenmesidir. Araştırma soruları ise şunlardır: (i) Stratejik yönetim ilkeleri aile işletmelerinin kurumsallaşması aşamasında etkin rol oynayabilir mi? (ii) Aile işletmelerinin kurumsallaşma aşamasında stratejik yönetim ilkelerinin önemi nedir? (ii) $\mathrm{Bu}$ ilkeler aile işletmelerinin kurumsallaşmalarında ne denli ve ne yönde etkilidir? Bu araştırma sorularının yanıtlanabilmesi amacıyla anket çalışması yapılmış olup, Ankara İvedik Organize Sanayi Bölgesinde faaliyet gösteren çikolata ve şekerleme imalatı yapan 12 firma tespit edilmiştir. Bu kapsamda 12 firma ile görüşme yapılıp anket soruları gönderilmiş, 9 firmadan olumlu yanıt alınmıştır. Araştırmanın örneklemini 17 katılımcı oluşturmaktadır. Anketlerden doğrultusunda elde edilmiş verilerin bilgisayar ortamı ile SPSS 22.0 istatistik programında analizi sağlanmıştır. Yapılan çalışmanın kapsamında uygulanan anket verilerinin uygulama sonuçlarına göre; demografik bilgiler ANOVA, korelasyon ve regresyon analizleriyle ile incelenip değerlendirilmiştir.

\section{Aile İşletmeleri Kavramı}

Aile işletmeleri ile aile dişı işletmelerin birbirinden farklı olup olmadığının değerlendirilmesi sürecinde araştırmacılarının karşılaştığ 1 temel zorluklardan biri aile işletmeleri kavramının tanımlanması sorunsalıdır. Dünya genelindeki yer alan işletmelerin \%65-\%80'ini aile işletmelerinin oluşturması önemli noktalardan birisidir. Türkiye'de ise bu oran \%95'tir (Kebeci, 2011). Aile işletmelerin tanımlanmasında yaygın olarak kullanılan üç temel ölçüt mevcuttur: (i) ailelerin, söz konusu işletmelerin kontrollerinde söz sahibi olup olmaması durumu, (ii) ailelerin, bu tip işletmelerin yönetiminde söz hakkına sahip olup olmaması ve (iii) işletme sahipliğinin ve liderliğinin ailenin gelecek kuşaklarına bırakılmış olup olmamas1 (Athanassiou ve Crittenden, 2002: 139).

Aydıner (2008); aile işletmeleri açısından kavramın, aile geçimlerini sağlayacak olan veya miras dağılımının önlenmesi maksadı ile kurulmuş beraberinde aile geçimi sağlamak için icra eden birey yönetiminde olan, ayrıca yönetimin kademesindeki büyük bir bölümün de aile bireyleriyle doldurulmuş olması, kararlarda ise aile üyelerinin etki göstermesidir. Aile üyeleri içindeki en az iki kuşak ile çalışan işletmeler olarak tanımlanmaktadır (Aydıner, 2008).

Aile işletmesinin tanımlarında kimi ortak noktalar bulunmaktadır (Fındıkçı, 2011):

- Aileler tarafından kurulmuş olma,

- $\quad$ Aile üyelerinin arasındaki bir bireyin tarafindan başlatmış olması ayrıca ailenin iş odaklı içerisinde yer aldığı kurumsal yapı özelliğine haiz olması, 
- Ailelerin kendilerine has olan kültür ile geleneklerinin işlerine yansıtmada bir toplumsal yapı olması,

- Aile bireyleri içerisinden birden çok kişinin iş gören yapıya sahip olması,

- Genellikle de akraba ilişkilerinde yer alan girişimcilerin mevcudiyeti ve bu kişilerin yönetimde de aynı çoğunlukta yer aldıkları bir yapıya sahip olma,

- İşletme mülkiyetlerinin ailelere ait olması,

- Aileler ile işlerin karşılıklı etkileşiminin söz konusu olması,

- Aile işletmelerinin genelde mevcut varlıkların dağılmasının önlenmesi amaçlı kurulan birliktelikler olması,

- Genelde beraberlik ve birliğin devam ettirilmesi maksadını haiz organizasyonlar olmas1,

- Karar vericiler ve hâkim karakterlerin aynı aile üyelerinden oluşması,

- $\quad$ Aile üyeleri tek başına yaşamlarında devam etmeyi sağlayacak ayrıca iktisadi büyümede koruma fonksiyonuna sahip olması.

\subsection{Aile İşletmelerinin Özellikleri}

Aile işletmelerinin başlıca ayırt edici özellikleri ve onları meydana getiren temel unsurlar söz konusudur (Aydıner, 2008):

- Bireylerin arasında kan bağı ile işletme yönetimindeki kimin sorumluluk sahibi olacağının/olmayacağının belirlenmesinde önemli kıstaslar arasındadır.

- Mevcut olan yönetici veya daha öncesinde bulunan yöneticinin de çocuğu ya da çocuklarının yönetimde görev almaktadır.

- Aile bireylerinin içinden birinin işletmede bulunan mevcut konumu, bu kişinin aile içerisinde olan mevcut konumuna da etki etmektedir.

Aile işletmeleri, iş insanlarının aileleri ve işleri ile ve bunların birbirleri ile olan ilişkileri kısmen iç içe hale getirmektedir. $\mathrm{Bu}$ durum göz önünde bulundurulduğunda aile işletmelerinin özellikleri daha belirgin hale gelmektedir. Öncelikle bu tip işletmelerde kan bağ unsuru yetki ve sorumluluk paylaşımında önemli bir belirleyicidir. Mevcut veya önceki yöneticilerin çocukları da genelde yönetimde görev alır ve işletmenin ünü aileyle birlikte gelişim gösterir. Diğer bir deyişle aileyle işletmenin değeri arasında yüksek oranda nedensellik 


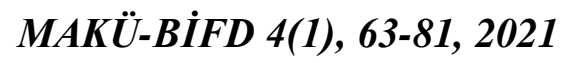

ilişkisi mevcuttur. Ayrıca, aile menfaatleriyle işletme politikaları arasında bă̆ mevcuttur (Fınd1kç1, 2011).

Kebeci (2011)’e göre ise aile işletmelerinin belirgin özellikleri şunlardır:

- İşletmenin yönetiminde çoğunluk olarak ailedeki iki kuşağın yer alması beraberinde eşin, kardeşin, ebeveynler ile çocukların arasındaki ortaklıkta aile şirketi tanımına girmektedir.

- İşletme politikasının aile menfaatlerine yansıması önemli noktalardandır. Aile varlıklarının korunmasındaki maksat ile kurulan işletmenin, kuşkusuz ki aile normlarından etkilendiği bilinmektedir.

- Kan bağı unsuru, personelin belirlenmesi ile diğer etkenlerle beraber öncelik taşımaktadır. İşletme sahiplerinin yakınlık göstermiş olduğu bireyler, çoğunluk olarak işletme içerisinde üst yöneticiler ile yakınlığının bulunmasıdır.

- Ailenin ismi ile şirketin isminde prestij bağlantılı olması, şirketteki iş ortamının yükseliş göstermekte olan konumunu aile toplumunda mevcut olan yükselme de etkili durumlardan biridir. Bu şekilde ise soy isminin ailedeki üyelerin prestij beklemede önemli rol oynadığını göstermektedir.

- Aile işletmelerindeki çalışan bireylere verilen senelik izin konularında ise esneklik gösterilmektedir.

Aile işletmelerine ilişkin tüm bu kriter, tespit ve tanımlamalar ışı̆̆ında bu işletmelerinin performansından yönetimine, kurum kültüründen, organizasyonel yapısına kadar birçok faktörün hem bir bütün olarak aile ile hem de tek tek aile içerisindeki bireyler ile yüksek derecede etkileşim içerisinde olduğu anlaşılmaktadır(Kebeci, 2011).

\section{Kurumsallaşma Kavramı}

Kurumsallaşma kavramı temelde kurum olabilme sürecini nitelemektedir. Bu kavram; işletmelerin yönetiminin/kontrolünün profesyonel yöneticilere bırakılması, büyük ölçüde bu profesyonel çalışanlarının stratejileri uyarınca hareket edilmesi, profesyonel danışmanların istihdam edilmesi gibi faaliyet ve politikaların benimsenmesi ile ilintilidir. Diğer bir deyişle, kurumsallaşma; işletmelerin "sistem durumuna gelebilme hali”dir (Pazarcık, 2004: 36).

İşletmeler yaşayan birer kurum biçimidir. $\mathrm{Bu}$ özellikleri neticesinde onların da kendilerine has kültürleri bulunmaktadır. Bu durum da işletmelerinin kültürüne paralel şekilde gelişme gösteren belli yazılı kuralların mevcudiyetini ve bunların çeşitli şekillerde personele 
duyurulması gerekliliğini beraberinde getirmektedir. $\mathrm{Bu}$ süreç de kurumsallaşmanın gereklilikleri arasında yer almaktadır (Kebeci, 2011).

Bununla birlikte, kurumsallaşma kavramı; patron ile aile üyelerinin yönetici konumundaki yer alan bireyler işlerinin bütünü ile profesyonel kişilere teslim etmesi değil de, tam tersini yapıp, patronların sürekli işlerin başında olması ile diğer çalışanlarla beraber kolektif birliktelik ayrıca takım ruhu ortaya çıkmasını da sağlamaktadır. (Alkış ve Temizkan, 2010).

\subsection{Aile İşletmeleri ve Kurumsallaşma}

Aile işletmesindeki zayıf yönleriyle beraber aile kavramının işletme kavramı ile birbirine karıştırılmasıdır (Alkış ve Temizkan, 2010). $\mathrm{Bu}$ tip işletmelerde, deneyim ile yeteneklere bakılmaksızın aile üyelerinin işe alınması ayrıca örgütsel hiyerarşinin de içerisinde yükseldiğini ortaya çıkarmaktadır. Dahası, kimi zaman bir takım aile bireylerine özel pozisyonlar oluşturulmaktadır (Aydıner, 2008). Fakat küreselleşme ve bu olgunun beraberinde getirdiği rekabet, bilgi üstünlükleri, teknolojiler gibi hızlı değişimler aile işletmelerini de dönüşüme zorlamaktadır. Böylesi bir ortamda, farklı yetenek, bilgi ve becerileri bulunan aile yöneticilerine duyulan gereksinim de artmaktadır (Pazarcık, 2004).

Aile işletmelerinin başarısızlıklarındaki en önemli nedenlerden biri de yönetimde ve kurumsallaşmada yetersizliktir (Genç, 2004). Başarının ve sürdürülebilirliğin sağlanabilmesi için, proaktif politikalar benimsenmeli ve kurumsal yapının oluşması sağlanmalıdır (Fındıkçı, 2011).

Tüm kurumlarda yazılı olan/olmayan bir çeşit kurallar bulunmaktadır. Bu düzen genellikle kurucu girişimciler tarafından belirlenmiş olup bu kişinin kurumdan bir şekilde ayrılmasına kadar uygulanmaktadır. Bu durum ise gayri-şahsi kuralların olmaması anlamında kısmen kuralsızlık olarak da nitelendirilebilir(Fındıkçı, 2011). Kurumsallaşma olgusu ise tam bu noktada karşımıza çıkmaktadır. Kuralsızlık durumunun potansiyel negatif etkilerinin elimine edilmesi anlamında kurumsallaşma gerçekleştirilmeli ve işletme ve aile kavramları ayrıştırılmalıdır, her iki unsurun kurumlaşması süreci başlatılmalıdır. Bu anlamda, işletmenin kurumsallaşması görece daha kolaydır (Aydıner, 2008). Bunun sebebi de zaten mevcut bir kurallar bütünün ve iyi ya da kötü bir şekilde işleyen bir sistemin mevcudiyetidir. Böylesi bir durumda yapılması gereken ise sistemdeki eksiklerin tespit edilmesi ve sistemin belirli bir düzen dâhilinde işlemesinin sağlanmasıdır (Pazarcık, 2004). Fakat ailelerin kurumsallaşması meselesi işletmenin kurumsallaşması kadar kolay olmayabilir. Ailelerin kendilerine özgü 


\section{MAKÜ-BİFD 4(1), 63-81, 2021}

kültürü vardır. $\mathrm{Bu}$ sebeple, kurumsallaşma sürecinde standart bir mekanizmanın yaratılıp benimsenmesi mümkün olmayabilir. Dolayısıyla, ailelerin kendilerine uygun olan bir sistem oluşturması ve benimsemesi gerekmektedir (Kebeci, 2011).

\section{Stratejik Yönetim}

Kişi ve kurumların belirsiz koşullar altında hedeflerine ulaşmasına yardımcı olan genel planlara strateji denir. Bu kavram; hedeflerin, önceliklerin, eylemlerin belirlenmesini ve bu eylemlerin gerçekleştirilmesi için kaynakların seferber edilmesi süreçlerini içerir. Hedeflere ulaşmada kullanılacak kaynakların kıtlığı ve zaman limiti strateji kavramını daha da önemli hale getirmektedir. Stratejik yönetim, stratejik planlama gibi alt kavramlar strateji kavramı temelinde şekillenmiştir (Bryson, 2017).

\subsection{Stratejik Yönetim Kavramı}

Kişi ve organizasyonların misyonu onların varlık sebebini/kuruluş -var oluş- amacını tanımlarken vizyon kavramı ise bu varlıkların gelecekte olmaları arzu edilen hal/durum/pozisyonları hakkında bilgi vermektedir. Dolayısıyla misyon kavramı kişi/organizasyonun hedeflerini ve bu hedeflere ulaşmadaki yaklaşımını tanımlamaktadır. Vizyon ise gelecekte olması istenen pozisyonu belirtmektedir. Stratejik yönetim ise organizasyonun vizyonuna doğru ilerlerken gerekli değiş̧iklikleri belirlemeye, yapmaya ve organizasyonun performansını ölçmeye yönelik bir sistem yaklaşımıdır (Wells, 1998).

Stratejik yönetim kavramı, en basit haliyle, gelecek için kurgulanmış olan bir yol haritası olarak adlandırılabilir. $\mathrm{Bu}$ yol haritası çeşitli yöntemleri bünyesinde barındırır. $\mathrm{Bu}$ yöntemlerin etkin şekilde uygulanması geleceğin yönetilmesi ve örgütün dinamik bir yap1 kazanması için olmazsa olmaz bir unsurdur (Dinçer, 1998).

$\mathrm{Bu}$ anlamda, stratejik yönetim; "bir organizasyonun faaliyetlerini, vizyonunu ve misyonunu belirleyen bir yönetim tekniği” olarak tanımlanabilir (Bryson, 2017). Stratejik yönetim, organizasyonun arzu edilen konuma getirilebilmesi için yapılması gerekenleri planlama, düzenleme, koordine etme ve kontrol etme süreçlerini ihtiva eder (Dinçer, 1998).

Stratejik yönetim, stratejik planın uygulanması ile sonuçların ölçülmesi ve değerlendirilmesini de içerir. Buradaki ölçme ve değerlendirme, yalnızca uygulamaların ve eylemlerin izlenmesinden ibaret değildir. Kuruluşun bu eylemlerin bir sonucu olarak nasıl değiştiğinin değerlendirilmesini ve bu değerlendirme sonucunda elde edilen bilgilerin genel planın güncellenmesi için kullanılmasını da bünyesinde barındırır (Wells, 1998: 5). 


\subsection{Stratejik Planlama ve SWOT Analizi}

Stratejik planlama, en yalın anlamıyla, bir organizasyonun stratejisinin tanımlanması ve bu stratejinin takip edilmesi amacıyla kaynakların tahsisi ve kararların alınması sürecidir. Stratejik plan stratejik yönetimin iskeletini oluşturur ve organizasyonun misyonunun, vizyonunun, değerlerinin, uzun vadeli hedeflerinin, bu hedeflere ulaşmak için kullanılacak olan eylem planlarının belirlenmesini mümkün kılar. Etkin olarak hazırlanmış bir stratejik plan, fırsatlara ve zorluklara karşı optimal düzeyde yanıt verilmesini sağlamak anlamında küçük işletmelerin büyümesinde ve başarılı olmasında kilit rol oynayabilir. SWOT analizi ise bir kişi veya kuruluşun güçlü yönleri, zayıf yönleri, firsatları ve tehditleri belirlemesine yardımcı olmak için kullanılan stratejik bir planlama tekniğidir (SWOT analizi, n.d.).

SWOT analizi, bir kuruluşun dâhili güçlü ve zayıf yanları ve dişsal firsatları ve tehditleri değerlendirmektedir. Dolayısıyla, SWOT analizi içsel ve dışsal olmak üzere iki temel analizden meydana gelmektedir. İçsel analize, kuruluşa özgü kaynakları, yetenekleri, temel yetkinlikleri ve rekabet avantajlarını tanımlamak için başvurulmaktadır (SWOT analizi, n.d.). Dışsal analiz ise rakiplerin kaynaklarına, endüstriyel ortamına ve genel iş atmosferine göre pazar firsatlarını ve tehditlerini tanımlamayı amaçlar. SWOT analizinin amacı, bir kuruluşun iç ve dış durumu hakkında sahip olduğu bilgileri kullanarak stratejinin bu bilgilere göre formüle edilmesini sağlamaktır (Sammut-Bonnici ve Galea, 2015). Stratejik yönetimden sorumlu kademenin belirlediği güçlü yönler, önlem almayı gerektiren zayıf yönler, dış çevre etkisiyle oluşan firsat ve tehditlerin birebir durum tespiti, ulaşılan bilgilerin sınıflandırılması, üretimde ve hizmette yüksek kaliteyi yakalamak, risklerin bertarafı için izlenecek yol ve yöntemlerin belirlenmesi bu analizle mümkündür (Ülgen ve Mirze, 2010: 36).

Yöntemi, 1960’lı y1llarda Harvard Üniversitesi’nin akademik personeli olan Learned, Christensen, Andrews ve Guth geliştirmiştir. SWOT analizinin en önemli özelliği, bir organizasyonda iç ve dış çevrenin stratejik yönetim bağlamında değerlendirilmesinde kullanılan bir analiz tekniği olmasıdır. $\mathrm{Bu}$ analizin işlevsel yararı ise çoğunlukla risk analizlerine gerek duyulmadan yararlı yönlere ilişkin çözümlemelerle zaman kaybının önlenmesi suretiyle risklere karşı kısa süre içinde önlem alınmasını sağlamasıdır (SWOT analizi, n.d.). Yapılan analizlerde belirlenen zayıf yönlerin güçlü yönlerden faydalanılması yoluyla giderilmesine çalışılmakta, tehditlerse işletme firsatları ile giderilmeye çalışılmaktadır. Stratejik yönetici için SWOT analizi bir nevi öz-sorgulama biçimidir (Eker, 2015). 


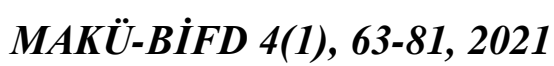

\section{Araştırmanın Metodolojisi}

Çalışmaya temel teşkil eden veriler anketler gerçekleştirilerek toplanmıştır. Anketlerden elde edilen veriler bilgisayar ortamında SPSS 22.0 istatistik programı aracılığıyla analiz edilmiştir. Aynı zamanda, çalışma kapsamında yapılan anket uygulamaları sonucunda elde edilmiş olan bulgular; demografik bilgiler, anova, korelasyon ve regresyon analizleriyle ile incelenip değerlendirilmiştir. Araştırma için İstinye Üniversitesi Sosyal ve Beşerî Bilimleri Araştırma Etik Kurulu'nun 21.01.2021 tarihli toplantısında, 2021/01 toplantı sayısı ve 04 karar sayısı ile "Etik Kurul İzni”" verilmiştir.

\subsection{Araştırmanın Amacı ve Önemi}

Küreselleşme ve beraberinde gelen rekabetçi ortam stratejik yönetim ve kurumsallaşmayı aile şirketleri için elzem hale getirmiştir. $\mathrm{Bu}$ açıdan bakıldığında, aile şirketlerinde stratejik yönetim ve kurumsallaşma sürdürülebilirlik ve rekabet anlamında kilit rol oynayan kavramlardandır. Bu araştırmanın amacı aile işletmeleri bazında stratejik yönetimin kurumsallaşma sürecindeki rolü ve etkisinin incelenmesidir.

\subsection{Araştırmanın Evreni ve Örneklemi}

Araştırmanın evreni olarak Ankara İvedik Organize Sanayi Bölgesinde faaliyet gösteren çikolata ve şekerleme imalatı yapan 12 aile firması tespit edilmiştir. Bu kapsamda 09 Aralık-28 Aralık 2019 tarihleri arasında hazır yiyecek imalatı yapan 12 firma ile görüşme yapılıp anket soruları gönderilmiş, 9 firmadan olumlu yanıt alınmıştır. Araştırmanın örneklemini ise 217 katılımcı oluşturmaktadır.

$\mathrm{N}$ : Evrenin birim sayıs1

n: Örneklem büyüklüğü

e: örneklem hatas1

Evrendeki elemanın sayısının bilindiğindeki formül:

$\mathrm{n}=\mathrm{N} / \mathbf{1}+\mathrm{Ne} 2$

Güvenilirlik düzeyi oranı \%95 olarak alınarak, örneklem genişliği ise $\pm 10 \%$ hassasiyeti $\mathrm{N}=460.826$ beraberinde $\mathrm{n}=82$ sonucu elde edilmiştir. Araştırmada çıkan bulgular neticesinde formdaki eksik ile hatalı doldurulan veriler ise kapsam dışında bırakılmıştır. Araştırmada 37 birey görüşmeyi kabul etmemiştir. 22 adet anket formunda ise eksik ve hata doldurulmuş 
olması araştırmanın dışında kalmıştır. Dolayısı ile araştırmaya katılan 217 bireyin görüşleri ile sonuçlar ele alınmıştır.

\begin{tabular}{|l|c|c|}
\hline Evren büyüklüğü & e & n \\
\hline 460.826 & 0.10 & 82 \\
\hline
\end{tabular}

\subsection{Araştırmanın Varsayımları:}

1. Ölçek soruları doğrultusunda hazırlanan içerik ve hazırlanış yöntemi, çalışmanın amacını gerçekleştirebilmesi yönünde yeterli olacaktır.

2. Anket katılımcıları ölçek sorularını bilimsel bir yaklaşım ile cevaplayacaktır.

\section{Hipotezleri:}

\begin{tabular}{|l|l|}
\hline H1 & $\begin{array}{l}\text { H0: Katılımcı bireylerin demografik özelliklerine göre, kurumsallık düzeylerinde etki } \\
\text { göstermemektedir. } \\
\text { H1: Katılımcı bireylerin demografik özelliklerine göre, kurumsallık düzeylerini } \\
\text { etkilemektedir. }\end{array}$ \\
\hline H2 & $\begin{array}{l}\text { H0: Katılımcı bireylerin demografik özelliklerine göre, sürdürülebilirlik etki } \\
\text { göstermemektedir. } \\
\text { H2: Katılımcı bireylerin demografik özelliklerine göre, sürdürülebilirlik } \\
\text { etkilemektedir. }\end{array}$ \\
\hline H3 & $\begin{array}{l}\text { H0: Katılımcı bireylerin demografik özelliklerine göre, stratejik yönetim açısından etki } \\
\text { göstermemektedir. } \\
\text { H3: Katılımcı bireylerin demografik özelliklerine göre, stratejik yönetim açısından } \\
\text { etkilemektedir. }\end{array}$ \\
\hline
\end{tabular}

\subsection{Araştırmanın Modeli}

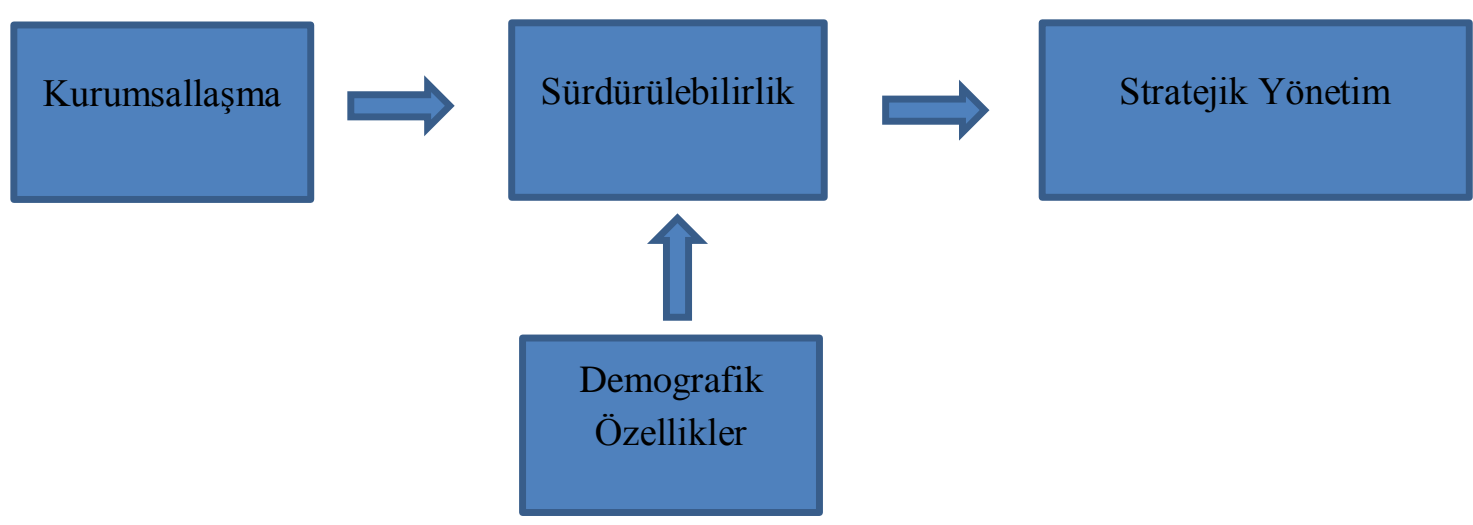

Şekil 1. Araştırma modeli 


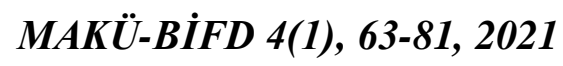

$\mathrm{Bu}$ araştırma betimsel yöntemle ve ilişkisel tarama modelleriyle gerçekleştirilmiştir. İlişkisel tarama modelleri, ikiden çok sayıda değişken arasında birlikte değişim varlığı veya derecesinin belirlenmesi için oluşturulan araştırma modelleridir (Karasar, 2010). Katılımcıların özelliklerinde hiçbir değişiklik yapılmaksızın veri toplanır, mevcut duruma dair katılımcı görüşlerinin alınmasına çalışılmıştır.

Betimleme yöntemi ise geçmişi ya da mevcut durumun o anki şekli ile betimlenmesi üzerine kurulu araştırma yöntemidir. Araştırma konusu olay, kendine has koşullarda ve olduğu şekli ile tanımlanması yöntemi uygulanır. Olayın etkilenmesine ve değiştirilmesine çaba gösterilmez. Önemli olan öğrenilecek şeyin gözlemle belirlenmesidir (Karasar, 2010).

\subsection{Ampirik Bulgular}

Uygulanan ölçek güvenirlilik katsayısı Cronbah alfa yöntemi ile test edilmiştir. Cronbah alfa değeri sonuçlarına göre sürdürülebilirlik ölçek sorularına göre 972, stratejik yönetim sorularına göre 892, kurumsallaşma sorularına göre ise 697 , bulunmuştur. Buda ölçeğin uygulanabilmesi için yeterli bir güvenirliğe sahip olduğunu göstermektedir.

\section{Kurumsallık Ölçeği}

Kurumsallaşma düzeyini ölçmek amacıyla (Wallace, 1995/5) tarafindan geliştirilen ölçek soruları yer almaktadır. Araştırmada, kurumsallaşmak için ele alınan unsurlar sırası ile formalleşme, kültürel güç, profesyonelleşme, esneklik, şeffaflık, sosyal sorumluluk ve tutarlılık sorularında güvenirlik ve geçerlilik ölçeklerinin test edildiği 5'li Likert'li sorulardan konu ile ilgili seçilmiş sorulardan kullanılmıştır. Güvenirlik için Cronbanh Alfa değerinin $\alpha=0,890$ olması ile kullanılan güvenilir ve geçerliği olduğu görülmüştür.

\section{Sürdürülebilirlik Ölçeği}

Çalışmanın kavramsal modelinde yer alan sürdürülebilirlik ölçeği başlığı altında devir planı, bağımsız yönetim kurulu ve çatışma yönetimi ölçekleri kullanılmıştır. Bu ölçekler için kavramsal model ve ilgili araştırmanın sürdürülebilirlik ölçeği kullanılmıştır. İlgili çalışma bu ölçeği geliştirirken, Chua vd. (1999), Sonfield ve Lussier (2004), yaptığı çalışmalardan yararlanmıştır. Ölçek, tanımlayıcı istatistikler doğrultusunda onbir açık uçlu soruyla, aile şirketlerinde mevcut değer algılarının ölçüldüğü 5'li Likert ölçeğinde sorularla aile odaklı amaçları ölçen sıralama soruları, aile şirketlerindeki mekanizmaların olup olmadığını ölçen soru ve aile içindeki gerilime sebep olma derecesini ölçen 5'li Likert'li sorulardan konu ile ilgili seçilmiş sorulardan kullanılmıştır. Güvenirlik için Cronbach Alfa değerinin $\alpha=0,920$ olması ile kullanılan güvenilir ve geçerliği olduğu görülmüştür 
Bunun yanı sıra katılımcı ölçek sonuçlarına verilen puan toplamı ile Görüş Puanları hesaplanmıştır. Puan 24 ile 120 arası değerlere sahiptir. $\mathrm{Bu}$ puanın yükselmesi aile işletmelerinde kurumsallaşma görüşünün olumlu şekilde yükseldiği, puanın düşmesi olumsuz şekilde azaldığ 1 nı göstermiştir.

Tablo 1. Güvenirlik analizi

\begin{tabular}{|c|c|c|}
\hline & Cronbach's Alpha & $\mathrm{N}$ of Items \\
\hline Sürdürülebilirlik & 972 & 5 \\
\hline Stratejik Yönetim & ,892 & 9 \\
\hline Kurumsallașma & 697 & 23 \\
\hline
\end{tabular}

Araştırmanın güvenirlik analizi incelendiğinden hem sürdürülebilirlik, hem stratejik yönetim hem de kurumsallaşma açısından güvenilir olduğu görülmektedir.

Tablo 2. Demografik özellikler

\begin{tabular}{|c|c|c|c|}
\hline & & $\mathrm{f}$ & $\%$ \\
\hline \multirow[t]{2}{*}{ Cinsiyet } & Kadın & 114 & 52,53 \\
\hline & Erkek & 103 & 47,47 \\
\hline \multirow[t]{4}{*}{ Yaş } & $18-22$ & 28 & 12,90 \\
\hline & $23-26$ & 102 & 47,00 \\
\hline & $27-34$ & 61 & 28,11 \\
\hline & 35 ve üzeri & 21 & 9,67 \\
\hline \multirow[t]{2}{*}{ Medeni Durum } & Evli & 145 & 66,82 \\
\hline & Bekar & 72 & 33,18 \\
\hline \multirow[t]{5}{*}{ Ĕgitim Durumunuz } & İlkokul & 29 & 13,36 \\
\hline & Lise & 40 & 18,43 \\
\hline & Ön Lisans & 59 & 27,18 \\
\hline & Lisans & 70 & 32,25 \\
\hline & Y.Lisans-Doktora & 20 & 9,22 \\
\hline \multirow[t]{6}{*}{ Aile Geliri } & $1000-1500$ & 21 & 9,23 \\
\hline & $1501-2000$ & 50 & 23,04 \\
\hline & $2001-2500$ & 42 & 19,35 \\
\hline & $2501-3000$ & 30 & 13,82 \\
\hline & $3001-3500$ & 29 & 13,36 \\
\hline & 3500 ve üzeri & 45 & 21,19 \\
\hline Toplam & & 217 & 100 \\
\hline
\end{tabular}

Katılımcıların \% 52,53'ü kadın, \% 47,47'si erkektir. \% 12,90’ı 18-22 yaş arası, \% 44'ü 23-26 yaş arası, \% 28,11'i 27-34 yaş arası ve \% 9,67'i 35 yaşında ve üzerindedir. Katılımcıların \% 66,82'si evli, \% 33,18'i bekardır. \% 13,36'sı ilkokul, \% 18,43'ü lise, \% 27,18'i ön lisans, \% 32,25'i lisans, \% 9,22'si yüksek lisans/doktora mezunudur. \% 9,23'ü 1000-0500 TL arası, \% 23,04'i 1501-2000 TL aras1, \% 19,35',i 2001-2500TL aras1, \% 13,82'si 2501-3000 TL aras1, \% 13,36's1 3001-3500 TL arası ve \% 21,19’u 3500TL ve üzeri gelir sahibidir. Bu bağlamda katılımcıların cinsiyet bağlamında çoğu kadın, yaş gurubu bağlamında çoğu 23-26 yaş arası 
grupta, medeni durum bağlamında çoğu evli, eğitim durumu bağlamında çoğu lisans mezunu, gelir durumu bağlamında 3500 €’den fazla gelire sahip kişilerden oluşmaktadır.

Tablo 3. Anket maddelerinin frekans analizi

\begin{tabular}{|c|c|c|c|c|c|c|c|c|c|c|c|}
\hline & \multicolumn{2}{|c|}{$\begin{array}{l}\text { Kesinlikle } \\
\text { Kat1liyorum }\end{array}$} & \multicolumn{2}{|c|}{ Katı11yorum } & \multicolumn{2}{|c|}{ Kararsızım } & \multicolumn{2}{|c|}{ Katılmiyorum } & \multicolumn{2}{|c|}{$\begin{array}{l}\text { Kesinlikle } \\
\text { Katılmıorum }\end{array}$} & \multirow[t]{2}{*}{ Ort. } \\
\hline & $\mathrm{f}$ & $\%$ & $\mathrm{f}$ & $\%$ & $\mathrm{f}$ & $\%$ & $f$ & $\%$ & $f$ & $\%$ & \\
\hline \multicolumn{12}{|c|}{ Aile Şirketi olmasının sürdürebilirlik yönleri } \\
\hline $\begin{array}{l}\text { İşletmedeki isim ile prestij, ailenin } \\
\text { ismi ile prestiji beraberinde gelişir }\end{array}$ & 106 & 48,85 & 26 & 11,98 & 38 & 17,51 & 22 & 10 & 25 & 11 & 3,76 \\
\hline $\begin{array}{l}\text { Ailenin prestiji için her türlü } \\
\text { fedakârlığa katlanılır }\end{array}$ & 59 & 27,19 & 49 & 22,58 & 58 & 26,73 & 25 & 11,52 & 26 & 11,98 & 3,41 \\
\hline $\begin{array}{l}\text { Ailenin bütün bireyleri işletmeye } \\
\text { hizmet eder }\end{array}$ & 107 & 49,31 & 32 & 14,75 & 33 & 15,21 & 24 & 11,06 & 21 & 9,68 & 3,83 \\
\hline $\begin{array}{l}\text { Çocuklar erken yaşta işletmeyi } \\
\text { tanıması ayrıca yapılan işleri de } \\
\text { tanımaktadır }\end{array}$ & 89 & 41,01 & 30 & 13,82 & 49 & 22,58 & 25 & 11,52 & 24 & 11,06 & 3,62 \\
\hline $\begin{array}{l}\text { Aile üyeleri işletmede alt düzeyden } \\
\text { başlayarak çalışmaktadır }\end{array}$ & 72 & 33,18 & 96 & 44,24 & 21 & 9,68 & 15 & 6,91 & 13 & 5,99 & 3,92 \\
\hline \multicolumn{12}{|l|}{ Stratejik Yönetim Yönleri } \\
\hline $\begin{array}{l}\text { İssletmemizin belli bir misyonu ve } \\
\text { vizyonu vardır. }\end{array}$ & 21 & 9,68 & 47 & 21,66 & 41 & 18,89 & 66 & 30,41 & 42 & 19,35 & 3,97 \\
\hline $\begin{array}{l}\text { İşletmenizin misyonu ve vizyonu } \\
\text { işletme faaliyetlerini eksiksiz } \\
\text { destekler. }\end{array}$ & 66 & 30,41 & 46 & 21,20 & 41 & 18,89 & 21 & 9,68 & 43 & 19,82 & 3,33 \\
\hline $\begin{array}{l}\text { İşletmemizin amaç ve hedefleri } \\
\text { vardır. }\end{array}$ & 34 & 15,67 & 36 & 16,59 & 86 & 39,63 & 39 & 17,97 & 22 & 10,14 & 3,10 \\
\hline $\begin{array}{l}\text { İşletmedeki stratejik amaç üst düzey } \\
\text { yöneticilerin mutabakat ile yazılı hâle } \\
\text { getirilmektedir }\end{array}$ & 15 & 6,91 & 22 & 10,14 & 54 & 24,88 & 89 & 41,01 & 37 & 17,05 & 2,49 \\
\hline $\begin{array}{l}\text { İşletmedeki stratejik plân, } \\
\text { performanstaki farklılıkların ile } \\
\text { düzeltmelerin prosedürünü } \\
\text { içermektedir. }\end{array}$ & 40 & 18,43 & 83 & 38,25 & 54 & 24,88 & 22 & 10,14 & 18 & 8,29 & 3,48 \\
\hline $\begin{array}{l}\text { İsletmemizin stratejik amaçları nicel } \\
\text { ve ölçülebilirdir. }\end{array}$ & 102 & 47 & 41 & 18,89 & 40 & 18,43 & 13 & 5,99 & 21 & 9,68 & 3,88 \\
\hline $\begin{array}{l}\text { İşletme stratejisi belirlenirken } \\
\text { çevredeki firsat ve tehditler } \\
\text { incelenmektedir }\end{array}$ & 89 & 41,01 & 52 & 23,96 & 32 & 14,75 & 13 & 5,99 & 31 & 14,29 & 3,71 \\
\hline $\begin{array}{l}\text { İşletme stratejisi belirlendikten sonra } \\
\text { ilgili plân ve bütçeler yapılmaktadır. }\end{array}$ & 98 & 45,16 & 21 & 9,68 & 52 & 23,96 & 17 & 7,83 & 29 & 13,36 & 3,65 \\
\hline $\begin{array}{l}\text { Rekabette avantaj sağlayabilecek } \\
\text { stratejik işbirlikleri işletmemiz için } \\
\text { faydalıdır. }\end{array}$ & 70 & 32,26 & 27 & 12,44 & 66 & 30,41 & 30 & 13,82 & 24 & 11,06 & 3,41 \\
\hline \multicolumn{12}{|l|}{ Kurumsallaşma Ölçeği } \\
\hline $\begin{array}{l}\text { Şirket yönetimindeki değişim sürekli } \\
\text { destekleyen yapıda ve her zaman } \\
\text { açıktır }\end{array}$ & 37 & 17,05 & 51 & 23,50 & 67 & 30,88 & 44 & 20,28 & 18 & 8,29 & 3,21 \\
\hline $\begin{array}{l}\text { Şirketteki değişim ile gelişime karşı } \\
\text { yönelik faaliyetlerin planlı ve } \\
\text { sistematik biçimde gerçekleşmektedir. }\end{array}$ & 66 & 30,41 & 38 & 17,51 & 60 & 27,65 & 18 & 8,29 & 35 & 16,13 & 3,38 \\
\hline $\begin{array}{l}\text { Şirket, çevredeki değişimler } \\
\text { oluşmadan önce olası gelişmeleri } \\
\text { tahmin etmeye ve bu gelişmelere } \\
\text { hazırlıklı olmaya önem vermektedir. }\end{array}$ & 35 & 16,13 & 37 & 17,05 & 64 & 29,49 & 57 & 26,27 & 24 & 11,06 & 3,01 \\
\hline $\begin{array}{l}\text { Şirkette, çevredeki değişimler } \\
\text { istatistiksel verilerden ve piyasa } \\
\text { araştırmalarından yararlanılarak tespit } \\
\text { edilmektedir. }\end{array}$ & 92 & 42,40 & 76 & 35,02 & 14 & 6,45 & 21 & 9,68 & 14 & 6,45 & 2,72 \\
\hline $\begin{array}{l}\text { Sirkette, çevredeki değişimlere } \\
\text { adaptasyon kolaydır. }\end{array}$ & 88 & 40,55 & 68 & 31,34 & 22 & 10,14 & 14 & 6,45 & 25 & 11,52 & 3,13 \\
\hline $\begin{array}{l}\text { Şirket, çevre koşullarını etkileme } \\
\text { gücüne sahiptir. }\end{array}$ & 69 & 31,80 & 89 & 41,01 & 21 & 9,68 & 22 & 10,14 & 16 & 7,37 & 3,80 \\
\hline $\begin{array}{l}\text { Şirket, dış çevrenin yarattı̆̆ firsat ve } \\
\text { tehditleri değil, kendisinin güçlü ve } \\
\text { zayıf yönlerini tespit etmeyle ilgilenir. }\end{array}$ & 58 & 26,73 & 37 & 17,05 & 52 & 23,96 & 15 & 6,91 & 55 & 25,35 & 3,93 \\
\hline $\begin{array}{l}\text { Sirket, rakiplerin değişim ve gelişim } \\
\text { karşısındaki davranışlarını takip eder. }\end{array}$ & 64 & 29,49 & 28 & 12,90 & 56 & 25,81 & 16 & 7,37 & 53 & 24,42 & 3,16 \\
\hline
\end{tabular}




\begin{tabular}{|c|c|c|c|c|c|c|c|c|c|c|c|}
\hline $\begin{array}{l}\text { Şirkette sektör liderini takip etmeye } \\
\text { önem verilir. }\end{array}$ & 76 & 35,02 & 25 & 11,52 & 26 & 11,98 & 14 & 6,45 & 76 & 35,02 & 3,05 \\
\hline $\begin{array}{l}\text { Piyasada Pazar payı yüksek } \\
\text { ürün/hizmetlerin taklit edilerek } \\
\text { üretilmesine ve düşük fiyatla } \\
\text { satılmasına ağırlık verilir. }\end{array}$ & 92 & 42,40 & 65 & 29,95 & 24 & 11,06 & 22 & 10,14 & 14 & 6,45 & 3,93 \\
\hline $\begin{array}{l}\text { Kişinin aile içindeki konumu } \\
\text { işletmedeki pozisyonunu etkiler }\end{array}$ & 41 & 19,10 & 45 & 20,68 & 72 & 33,18 & 39 & 17,84 & 20 & 9,29 & 2,78 \\
\hline $\begin{array}{l}\text { Kararlar birlikte alınır ve uygulamaya } \\
\text { geçilir }\end{array}$ & 74 & 34,06 & 33 & 15,41 & 67 & 30,97 & 16 & 7,30 & 27 & 12,44 & 2,49 \\
\hline $\begin{array}{l}\text { Aile işletmesi olduğu için daha kısa } \\
\text { süreç içerisinde kararlar alınabiliyor }\end{array}$ & 39 & 18,06 & 33 & 15 & 68 & 31,34 & 50 & 23,12 & 27 & 12,39 & 2,96 \\
\hline $\begin{array}{l}\text { İşletmemizde stratejik kararları } \\
\text { sadece aile üyeleri verir }\end{array}$ & 100 & 46,08 & 67 & 30,82 & 16 & 7,23 & 18 & 8,52 & 16 & 7,23 & 2 \\
\hline $\begin{array}{l}\text { Aile üyelerinin birbirlerinin iyi } \\
\text { tanımalarında dolayı daha iyi bir } \\
\text { takım ruhuna sahip olduklarında } \\
\text { işletme iklimi başarılıdır }\end{array}$ & 92 & 42,40 & 60 & 27,58 & 25 & 11,35 & 12 & 5,68 & 28 & 12,90 & 2,19 \\
\hline $\begin{array}{l}\text { Aile üyelerinin iş ile ilgili } \\
\text { çatışmalarında problemleri yüz yüze } \\
\text { görüşerek çözmeyi tercih ederler }\end{array}$ & 25 & 11,52 & 41 & 19,06 & 46 & 21,16 & 58 & 26,76 & 47 & 21,68 & 3,29 \\
\hline $\begin{array}{l}\text { Aile işletmesi tatil günü ile mesai } \\
\text { konularında daha özverili } \\
\text { davranmaktadır }\end{array}$ & 61 & 28,11 & 33 & 15 & 58 & 26,84 & 13 & 6,08 & 52 & 23,96 & 2,83 \\
\hline $\begin{array}{l}\text { İşletmemizdeki bireyler işe daha çok } \\
\text { çaba göstermeleri ile boş } \\
\text { zamanlarında işleme açısından } \\
\text { değerlendirme firsatı bulunmaktadır }\end{array}$ & 65 & 29,95 & 25 & 11,35 & 63 & 28,90 & 14 & 6,49 & 51 & 23,50 & 2,83 \\
\hline $\begin{array}{l}\text { Yöneticilerin yönetim hususundaki } \\
\text { birikimleri ile değerleri ailedeki diğer } \\
\text { nesillere aktarma yönünde isteklidir }\end{array}$ & 76 & 35,02 & 22 & 10,14 & 29 & 13,42 & 12 & 5,68 & 78 & 35,94 & 2,98 \\
\hline $\begin{array}{l}\text { Kurucu ya da yöneticinin karar } \\
\text { almadaki ihtiyacının gerektiğinde aile } \\
\text { bireylerinin görüşü alınır }\end{array}$ & 98 & 45,16 & 57 & 26,36 & 27 & 12,39 & 19 & 8,92 & 16 & 7,23 & 2,07 \\
\hline $\begin{array}{l}\text { Kurucu ya da yöneticinin karar } \\
\text { almadaki ihtiyacının gerektiğinde } \\
\text { uzman görüşe başvurulur }\end{array}$ & 34 & 15,67 & 36 & 16,59 & 86 & 39,63 & 39 & 17,97 & 22 & 10,14 & 3,10 \\
\hline $\begin{array}{l}\text { Aile içerisindeki tartışmaların işletme } \\
\text { faaliyetlerinde oluşan engeller hızlı } \\
\text { şekilde çözüme ulaşır }\end{array}$ & 59 & 27,19 & 49 & 22,58 & 58 & 26,73 & 25 & 11,52 & 26 & 11,98 & 3,41 \\
\hline $\begin{array}{l}\text { Aile üyelerinin arasında güçlü ve } \\
\text { sürekli iletişim bulunmaktadır }\end{array}$ & 66 & 30,41 & 38 & 17,51 & 60 & 27,65 & 18 & 8,29 & 35 & 16,13 & 3,38 \\
\hline
\end{tabular}

Toplamda 217 bireye uygulanan sorulara verilen cevaplar doğrultusunda çıkan sonuçlara göre, katılımcılarca ölçeğe verilen cevapların dağılımı Tablo 3'te görülmektedir. Genel katılımda ortalama 3,22 bulunmuştur. Bu değer "katılıyorum" ve "kararsızım" cevap puan aralığına denk gelir. Dolayısıyla katılanların aile işletmelerindeki genel kanaat ortalamasının üzerinde "iyi”" seviyeye yakın olduğu belirlenmiştir. Aile işletmelerinde kurumsallaşmaya yönelik olumlu yönde aralarında anlaşmaya gidildiği izlenmektedir.

$\mathrm{Bu}$ bağlamda aile işletmelerinde kurumsallaşmanın sağlanmasının stratejik yönetim ilkeleri ile mümkün olduğu, rekabette avantaj sağlayabilecek stratejik iş birliklerinin aile işletmeleri için faydalı olduğu sonucuna ulaşılmıştır. Ayrıca, işletmenin stratejik plânının, performans farklılıkları ve düzeltmelerin de prosedürleri içermesi ve işletme stratejisi belirlendikten sonra ilgili plân ve bütçeler yapılmasının kurumsallaşma politikalarına uygunluğu da tespit edilmiştir. 


\subsubsection{Demografik Özelliklere Göre Görüş Farklılığı Değerlendirmesi}

Demografik özelliklere bağlı olarak görüşlerin farklılaşma durumunu incelemek üzere ttesti ve ANOVA uygulanmıştır. İlgili testlerin incelemesi \%95 anlamlılık düzeyindedir.

\subsubsection{Cinsiyet}

Cinsiyete göre katılımcı görüşlerinin farklılaşma durumu incelemesine göre;

Tablo 4. Cinsiyete göre görüşlerin farkları

\begin{tabular}{|c|c|c|c|c|c|}
\hline & Cinsiyet & $\mathrm{N}$ & Ortalama & $\mathrm{t}$ & $\mathrm{p}$ \\
\hline \multirow{2}{*}{ Görüş Puanları } & Kadın & 113 & 80,95 & \multirow{2}{*}{$-0,549$} & 0,567 \\
\cline { 2 - 4 } & Erkek & 104 & 82,52 & & \\
\hline Toplam & & 217 & 165,47 & & \\
\hline
\end{tabular}

Analiz değerindeki orana göre $\mathrm{p}>0,05^{\prime}$ dir ve kadınlarla erkeklerin görüş puanları arası istatistiksel bir fark bulunmamıştır.

\subsubsection{Yaş}

Yaşa göre katılımcı görüşlerinin farklılaşma durumları incelemesine göre;

Tablo 5. Yaşa göre görüşlerin farkları

\begin{tabular}{|l|l|l|l|l|}
\hline \multicolumn{2}{|c|}{} & Mean Square & F & Sig. \\
\hline Görüş Puanları & Grupların arasında & 98,69 &, 344 &, 889 \\
\hline & Gruplar içinde & 272,4 & & \\
\cline { 2 - 5 } & Toplam & 390,0 & & \\
\hline
\end{tabular}

Analiz değeri $\mathrm{p}>0,05^{\prime}$ dir ve farklı yaş grupları arası görüş puan ortalamaları arası fark istatistiksel yönden anlamlı bulunmamıştır.

\subsubsection{3. Ĕgitim}

Eğitim şekline göre görüşlerin farklılaşma durumu incelemesine göre;

Tablo 6. Eğitime durumlarına göre görüş farkları

\begin{tabular}{|l|l|l|l|l|}
\hline \multicolumn{2}{|c|}{} & Mean Square & F & Sig. \\
\hline Görüş Puanları & Grupların arasında & 107,7 &, 536 &, 583 \\
\cline { 2 - 5 } & Gruplar içinde & 206,8 & & \\
\cline { 2 - 5 } & Toplam & 315,7 & & \\
\hline
\end{tabular}

Analiz değeri $\mathrm{p}>0,05$ 'dir ve farklı eğitim seviyeleri arası görüş puan ortalamaları arası fark istatistiksel yönden anlamlı bulunmamıştır.

\subsubsection{Medeni Durum}

Medeni duruma göre katılımcı görüşlerinin farklılaşma durumu incelemesinde göre; 
Tablo 7. Medeni durumlarına göre görüş farkları

\begin{tabular}{|l|l|l|l|l|l|}
\hline & Cinsiyet & $\mathrm{N}$ & Ortalama & $\mathrm{t}$ & $\mathrm{p}$ \\
\hline \multirow{2}{*}{ Görüş Puanları } & Evli & 147 & 80,42 & $-0,475$ & 0,619 \\
\cline { 2 - 6 } & Bekar & 70 & 82,37 & & \\
\hline Toplam & & 217 & 162,79 & & \\
\hline
\end{tabular}

Analiz değeri $\mathrm{p}>0,05$ 'dir ve evlilerle bekarların görüş puanları arası fark istatistiksel yönden anlamlı bulunamamıştır.

\subsubsection{Aile Geliri}

Ailelerin gelir durumuna göre görüşlerin farklılaşma durumu incelemesine göre;

Tablo 8. Aile gelir durumlarına göre görüş farkları

\begin{tabular}{|l|l|l|l|l|}
\hline \multicolumn{2}{|c|}{} & Mean Square & F & Sig. \\
\hline Görüş Puanları & Grupların arasında & 181,7 &, 678 &, 583 \\
\hline & Gruplar içinde & 279,2 & & \\
\hline & Toplam & 480 & & \\
\hline
\end{tabular}

Analiz değeri $\mathrm{p}>0,05^{\prime}$ dir ve farklı gelir grubundaki katılımcılar arası görüş puan ortalamaları arası fark istatistiksel yönden anlamlı bulunamamıştır.

\subsection{Regresyon Analizi}

Regresyon analizinin amacı, iki veya daha fazla değişken arası ilişkilerin ölçülmesidir. Tanımlayıcı istatistiğin yanı sıra çıkarımsal istatistik de sağlamaktadır (Tonta, 2007). Regresyon değişkenler arası bağı analiz eder ve birbirlerini yordama durumlarına dair bilgi verir. Bu modelde aile işletmeleri arası kurumsallaşma boyutlarının genel görüşü anlamlı olarak yordama durumu incelenmiştir.

\begin{tabular}{|l|l|l|l|l|l|}
\hline Model & $\mathrm{R}$ & $\mathrm{R}^{2}$ & Düzelmiş $\mathrm{R}^{2}$ & Tahminin Standart Hatas1 \\
\hline 1 & 0,981 & 0,972 & 0,96 & 0,1849 \\
\hline \multicolumn{7}{|l|}{} \\
\hline Model & $\begin{array}{l}\text { Karelerin toplam } \\
\text { değeri }\end{array}$ & $\begin{array}{l}\text { Serbestlik } \\
\text { Oranı }\end{array}$ & $\begin{array}{l}\text { Karelerin } \\
\text { Ortalama değeri }\end{array}$ & $\mathrm{F}$ & Sig. \\
\hline Regresyon & 467,930 & 6 & 148,520 & 4371,314 & $0^{\mathrm{b}}$ \\
\hline Kalan & 0,687 & 140 & 0,049 & & \\
\hline Toplam & 498,537 & 145 & & & \\
\hline
\end{tabular}

\begin{tabular}{|l|l|l|l|l|l|l|}
\hline & \multicolumn{2}{l}{$\begin{array}{l}\text { Standartlanmamış } \\
\text { Katsayılar }\end{array}$} & \multicolumn{2}{l|}{$\begin{array}{l}\text { Standartlaştırılmış } \\
\text { Katsayılar }\end{array}$} & & \\
\hline Model & B & Std. Eror & Beta & T & Sig. & VIF \\
\hline (Sabit) & 33,418 & 0,778 & & 46,463 & 00 & \\
\hline $\begin{array}{l}\text { Aile Şirketi olmasında } \\
\text { sürdürebilirlik yönleri }\end{array}$ & 0,832 & 0,18 & 0,868 & 46,833 & 00 & 4,400 \\
\hline Stratejik Yönetim & $-0,524$ & 0,18 & 0,380 & $-42,459$ & 00 & 1,028 \\
\hline $\begin{array}{l}\text { Aile İşletmelerinde Büyümeye } \\
\text { Yönelik Yönleri }\end{array}$ & 0,026 & 0,18 & 0,027 & 1,437 & 0,170 & 4,458 \\
\hline Küumsallaşma Ölçeği & 0,893 & 0,12 & 0,886 & 48,821 & 00 & 4,612 \\
\hline
\end{tabular}




\section{MAKÜ-BİFD 4(1), 63-81, 2021}

Yukarıdaki analizde p değeri 0 yani 0,05 'in altında olduğundan; bağımlı ve bağımsız değişkenler arası ilişki anlamlıdır. Değişkenler için p değerleri analiz edilecek olursa; tüm bağımsız değişkenlerden yalnız 'Aile İşletmelerinde Büyümeye Yönelik Yönleri' boyutu, bağımlı değişken olan "genel görüş” kavramıyla anlamlı bir ilişki sahibi değildir.

Regresyon analiz sonucu; üzerinde çalışılan model anlamlı olup “aile işletmelerinin kurumsallaşmaya yönelik düşünceleri’ bağımlı değişkeni üzerindeki etkisi anlamlıdır.

\section{SONUÇ}

Hızla değişen dünya ve rekabetçi ekonomik atmosfer ekonomi alanındaki aktörleri de aynı şekilde değişime zorlamaktadır. Bu değişim gereksinimi başarı ve sürdürülebilirlik için elzem bir konum elde etmiştir. Bu süreçten birincil derecede etkilenen aktörelerden biri de aile işletmeleridir.

$\mathrm{Bu}$ bağlamda, aile işletmelerinin varlıklarını koruyabilmeleri ve sürdürülebilir başarı sağlamaları anlamında gerçekleştirmeleri gereken en önemli değişimlerden biri kurumsallaşmadır. Kurumsallaşma ise temelde firmanın bir lider yerine bir sisteme bağlı yönetim şekline geçmeleriyle sağlanabilmektedir ve stratejik yönetim ilke ve uygulamaları ile yakın ilişki ve etkileşim içerisindedir. Etkin işleyen bir sistemi yerleştirmeyi amaçlayan bu süreç işletmedeki tüm unsurları bir düzene sokmayı hedeflemektedir.

Araştırma hipotezleri kurumsallık düzeyi, sürdürülebilirlik niteliği ve aile şirketi olma değişkenleri ile cinsiyet durumunun ilişkileri üzerine kurulmuş olup analiz değerindeki orana göre $\mathrm{p}>0,05$ 'dir ve kadınlarla erkeklerin görüş puanları arası istatistiksel bir fark bulunmamış, analiz değeri $\mathrm{p}>0,05^{\prime}$ dir ve farklı yaş grupları arası görüş puan ortalamaları arası fark istatistiksel yönden anlamlı bulunmamış, analiz değeri $\mathrm{p}>0,05$ ' dir ve farklı eğitim seviyeleri arası görüş puan ortalamaları arası fark istatistiksel yönden anlamlı bulunmamış, Analiz değeri p>0,05'dir ve evlilerle bekarların görüş puanları arası fark istatistiksel yönden anlamlı bulunamamış, Analiz değeri p>0,05'dir ve farklı gelir grubundaki katılımcılar arası görüş puan ortalamaları arası fark istatistiksel yönden anlamlı bulunamamıştır.

Toplamda 217 kişi üzerinde sorulan sorulara verilen cevaplara göre, katılımcıların ölçekler verdikleri cevapların dağılımı bağlamında genel katılımda ortalama 3,22 olarak hesaplanmıştır. Bu değer "katılıyorum" ve "kararsızım" cevap puan aralığına denk gelmiştir. $\mathrm{Bu}$ nedenle katılımcıların aile işletmelerinde sergiledikleri genel kanaat ortalaması üzerinde “iyi” seviyeye yakın olduğu saptanmıştır. Aile işletmelerinde kurumsallaşmayla ilgili olumlu yönde aralarında anlaşma olduğu izlenmektedir. Bu nedenle aile işletmelerinde kurumsallaşma 
sağlanmasının stratejik yönetim ilkelerinin gerçekleşmesi ile mümkün olacağı, rekabette avantaj sağlanabilecek stratejik iş birliklerinin aile işletmelerine faydası olduğu sonucuna ulaşılmıştır. Ayrıca, işletmenin stratejik planının, performans farklılıkları ve düzeltmelerin prosedürlere uyması ve işletme stratejisinin belirlenmesinin ardından ilgili plan ve bütçe yapılmasının kurumsallaşma politikalarına uygunluğu da saptanmıştır.

Stratejik yönetim kavramı küresel ekonomiyi etkisi altına almış bulunan değişimci ve gelişimci süreç ve rekabetçi ekonomik ortam şartlarında firmaların kurumsallaşmasına olanak veren yeni fikirler sayesinde aile işletmelerinin gelişimine ve başarıya ulaşmasına yardımcı olma potansiyeline sahiptir. Bu anlamda, aile işletmeleri kurumsal yönetim çerçevesinde temel politikalara yön verecek ve de vizyonları ve misyonları doğrultusunda tüm taleplere imkanlar dahilinde cevap sağlayacak bir stratejik yönetim belirlemelidirler.

Aile işletmeleri rekabetçi ortama karşı almaları gereken pozisyonlara dönük bir stratejik yönetim benimsemelilerdir. Bu çerçevede amacı aile işletmelerinin kurumsallaşma aşamasında stratejik yönetim ilkeleri oldukça etkin ve önemli bir rol oynamaktadır. Dolayısıyla, stratejik yönetim ilkeleri kurumsallaşmanın sağlanmasına önemli ölçüde katkıda bulunmaktadır.

\section{KAYNAKÇA}

Alkış H., \& Temizkan V. (2010). İşletmelerin kurumsallaşma düzeylerinin belirlenmesi: (haddehaneler)karabük demir çelik sektörü örneği. Ekonomik Yaklaşım, 21(76), 73-92

Athanassiou, N., \& Crittenden, W.F. (2002). Founder centrality effects on the mexican family firm's top management group: firm culture, strategic vision and goals, and firm performance, Journal of World Business, 37(2), 139-150

Aydıner T. (2008). Aile işletmelerinde ikinci kuşağın örgütsel bağlılık anlayışının incelenmesi: İzmit Ticaret Odası'na bağlı aile işletmelerinde bir uygulama. Yayınlanmamış Yüksek Lisans Tezi, Kocaeli Üniversitesi, Sosyal Bilimler Enstitüsü, İşletme Anabilim Dalı.

Bryson, J. (2017). Strategic planning for public and nonprofit organizations (a guide to strengthening and sustaining organizational achievement). San Francisco: Jossey Publishers. 10.02.2021 https://www.wiley.com/en-us/exportProduct/pdf/9781119071617

Chua, J.H., Chrisman, J.J., \& Sharma, P. (1999). Defining the family business by behavior. entrepreneurship theory and practice, 23, 19-39.

Dinçer, Ö. (2007). Stratejik yönetim ve işletme politikası. Alfa Yayınları.

Eker, Ö. (2015). 2023'e doğru 3. doğa ve ormancılık sempozyumu doğal rekreasyon alanlarının yönetsel, yapısal ve sosyo-ekonomik açıdan değerlendirilmesi: Başkonuş rekreasyon alanı örneği,

Erişim Tarihi:

10.12.2020, https://ormuh.org.tr/uploads/docs/06122015_3.DOGASEMKITABI_KITAP.pdf, 321-329

Fındıkçı İ., (2011). Aile işletmeleri, Alfa Yayınları, Genişletilmiş 4. Basım. 
Genç, N., \& Karcığlu F. (2004, Nisan 17-18). Aile işletmelerinin karşılaştıkları sorunlar ve çözüm önerileri, bir uygulama. I. Aile İşletmeleri Kongresi Bildiriler Kitabı, İstanbul Kültür Üniversitesi Yayını, Yayın No: 40

Karasar, N. (2010). Bilimsel araştırma yöntemi. Nobel Yayınevi.

Kebeci T. (2011). Aile işletmelerinde yönetim anlayışı ve kurumsallaşma. İkinci Adam Yaymlar1.

Pazarcık O. (2004, Nisan 17-18). Aile işletmelerinin tanımı kurumsallaşması ve yönetişimi. İstanbul Kültür Üniversitesi, I. Aile İşletmeleri Kongresi Bildiriler Kitabı, İstanbul Kültür Üniversitesi Yayınları, Yayın No: 40.

Sammut-Bonnici, T., \& Galea, D. (2015). SWOT analysis. In C. L. Cooper (Ed.), Wiley Encyclopedia of Management (pp. 1-8). John Wiley \& Sons, Ltd. https://doi.org/10.1002/9781118785317.weom120103

Sonfield, M.C., \& Lussier, R. N. (2004). First, second-, and third-generation family firms: A comparison. Fam. Bus. Rev., 17 (2004), 189-201

SWOT Analizi. (n.d.). Pazarlama ve Yönetim kategorisi içinde. https://tr.wikipedia.org/wiki/SWOT_analizi

Ülgen, H., \& Mirze, S. K. (2010). İşletmelerde stratejik yönetim, Beta yayınları, İşletmeEkonomi Dizisi: 581, 6. Bask1.

Wallece, J. E. (1995). Organizationaland professional commitment in professional and nonprofessional organizations administrative science quarterly, 40(2), 228-255. Erişim Tarihi: 02.01.2021 https://www.jstor.org/stable/2393637?origin=crossref, https://doi.org/10.2307/2393637

Wells, Denise Lindsey. (1998). Strategic management for senior leaders: A handbook for implementation. [Washington, D.C.] :Dept. of the Navy, Total Quality Leadership Office. Erişim Tarihi: 01.10.2020, http://dr-ama.com/wp-content/uploads/2013/05/strategic-planningfor-senior-leaders.pdf 